\title{
Transected Talus Inflicted during a Soft Tissue Release for Congenital Talipes Equino Varus: A 17 year follow up
}

\author{
by Manzoor Ahmed Halwai, MS ${ }^{1}$, Shabir Ahmed Dhar, MS ${ }^{2} \rrbracket$, Murtaza Fazal Ali, MS ${ }^{3}$, \\ Mohammed Farooq Butt, MS ${ }^{4}$, Mohammed Ramzan Mir, MS ${ }^{5}$, Altaf Ahmed Kawoosa, MS ${ }^{6}$
}

The Foot \& Ankle Journal 1 (10): 3

A case of transected talus that occurred during surgical Talipes Equino Varus (club foot) correction in childhood is presented. Seventeen years later, the patient is asymptomatic and free of pain. One of the complications that can occur during clubfoot soft tissue release is sectioning of the talar head. This case demonstrates that favorable long term results are possible with this type of complication.

Key words: Congenital Talipes Equino Varus deformity, club foot, transected talus

Accepted: September, 2008

Published: October, 2008

This is an Open Access article distributed under the terms of the Creative Commons Attribution License. It permits unrestricted use, distribution, and reproduction in any medium, provided the original work is properly cited. @The Foot \& Ankle Journal (www.faoj.org)

The posteriomedial release for correction of congenital talipes equinovarus (CTEV) or club foot defromity was proposed in 1906 by Codvilla and reiterated in the more recent literature by Turco. ${ }^{1,2}$ The foundation of successful surgery focuses on a complete reduction with extensive release of the posterior, medial, subtalar and plantar soft tissue contractures and $\mathrm{K}$ wire fixation.

Address correspondence to: Shabir Ahmed Dhar, MS

Government Hospital for Bone and Joint surgery ,Bagat Barzulla, Srinagar

Kashmir, 190005.

Email: shabirdhar@yahoo.co.in

${ }^{1-6}$ All these authors can be reached at the Government Hospital for Bone and Joint surgery ,Bagat Barzulla, Srinagar Kashmir, 190005.
Several complications have been reported in the surgical management of club foot. These include wound healing and scarring, residual equinus, cavus, calcaneal gait, persistent forefoot adduction and hind foot valgus. ${ }^{3}$

This case report presents a 17 year follow-up where during the posteromedial release, the talus was transected.

\section{Case Report}

A 17 year old male reported to the outpatient department of our hospital for the management of a callosity of the right foot. The patient's medical history revealed that he had been operated for CTEV of the left foot at an age of 4 months. 


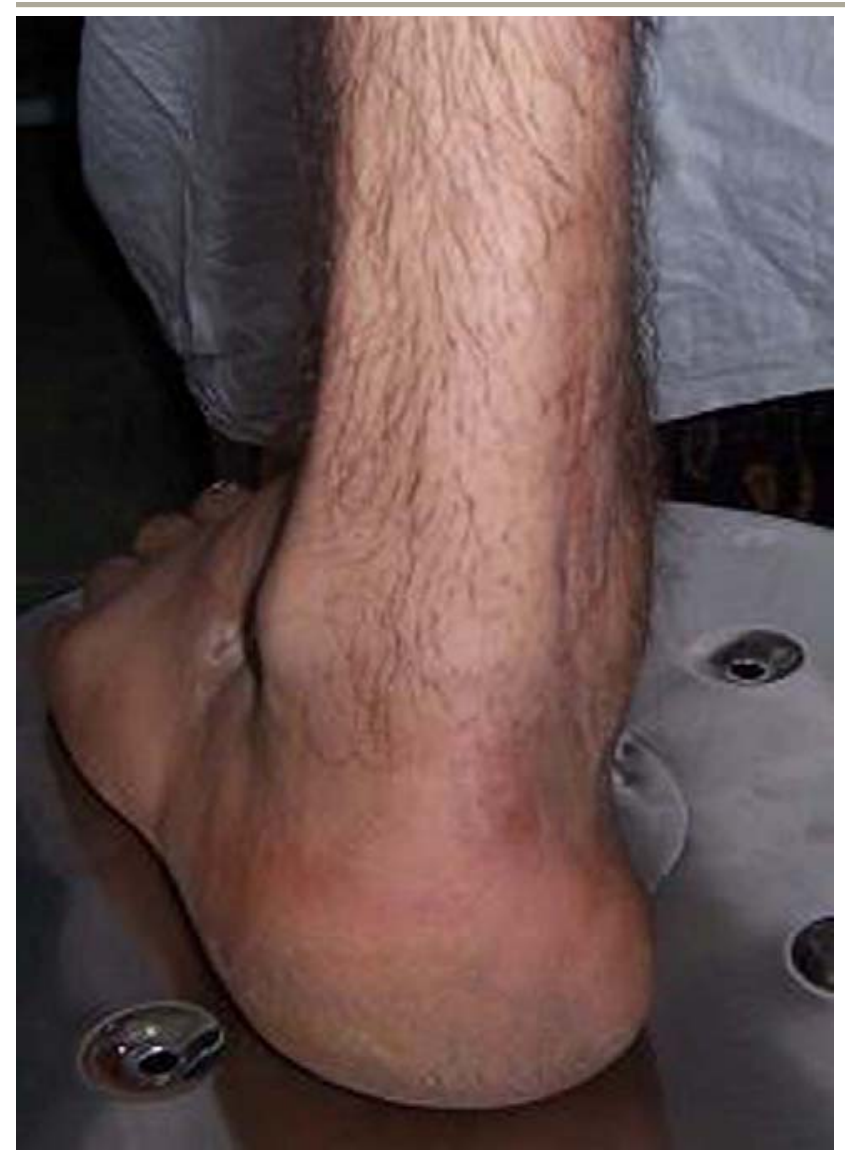

Figure 1 After 17 years, the foot remains in a slight heel varus with excellent correction.

Clinical examination of the operated foot revealed a plantigrade foot with mild heel varus. (Fig. 1) The arch of the foot was well maintained. (Fig. 2) The patient was pain free and reported no abnormal shoe wear.

The patient was not able to produce the operative records from the hospital where he had the surgery, but his father was able to recall that a pin had been placed in the foot. He also stated that he had been informed that his child would require a slightly different post operative regimen due to an operative complication.

The range of motion at the ankle was 10 degrees of dorsiflexion and 25 degrees of plantarflexion. There was no scarring and the talocalcaneal index was more than 20 degrees. The patient was classified into the good category as per the criteria of Brougham, et al. ${ }^{4}$

(C) The Foot \& Ankle Journal, 2008

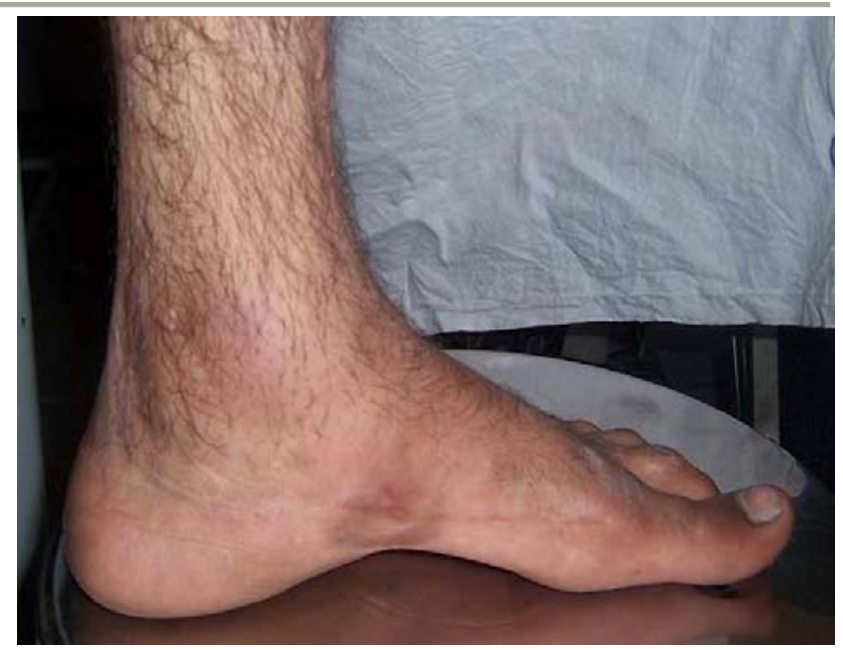

Figure 2 After 17 years, the foot maintains a well constructed arch with only minimal scarring of the foot following CTEV release.

The patient consented to the radiographic examination of the left foot, which showed that the talus had a clear area of radiolucency along the transected part. (Fig. 3) The overall contour of the bone was maintained. The radiograph in the anterior posterior plane showed a wedge shaped navicular. (Fig. 4)

\section{Discussion}

Among the most characteristic osseous disturbances seen after the treatment of the CTEV are those involving the tarsal navicular. According to Napontiek, decreased size of the ossification centre, flattening, fragmentation, cyst like changes and wedging of this bone are seen. ${ }^{5}$

The talus is particularly vulnerable in terms of avascular necrosis with an incidence of $14.3 \%$. In a series of 104 clubfeet, Laaveg. et al., reported that wedge-shaped navicular bones caused abnormal loading. ${ }^{7}$ Talonavicular subluxation and avascular necrosis of the calcaneus have been reported by Magone, et al. ${ }^{6}$ 


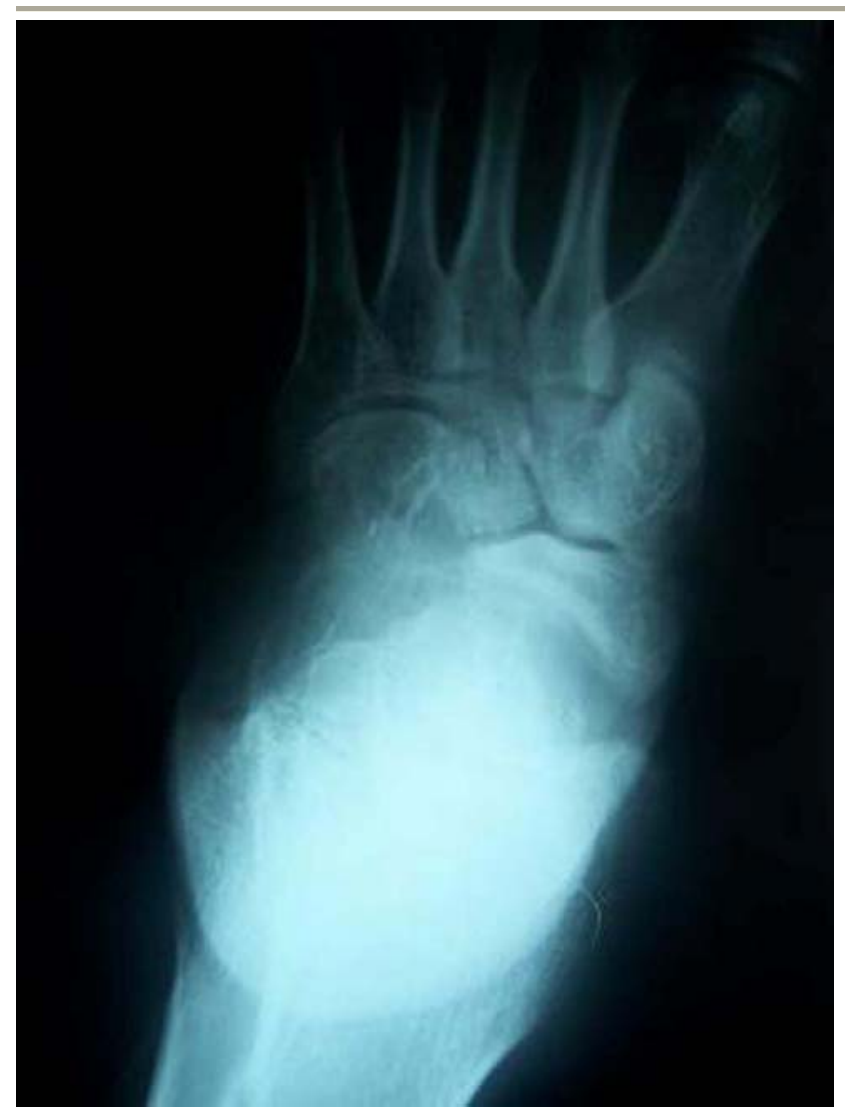

Figure 3 There is a wedge-shaped navicular without loss of significant range of motion to the joint.

Other complications include the transection of the sustentaculam tali, sectioning of the head of the talus, aseptic necrosis of the talus and navicular. ${ }^{9}$ Occasionally the biomechanics of cast treatment lead the surgeon to suspect that the head of the talus has been amputated, as flattening is seen on radiograph. This is often caused by aggressive soft tissue release of the talonavicular joint and not recognizing that the talar head often lies deep within the joint. If the surgeon is overly aggressive with the soft tissue release the talar head can be sectioned or injured.

Even though this surgical error is considered as severe, which often require $\mathrm{k}$-wires to stabilize the talar head, this case report demonstrates that a good functional result is still possible. This patient had no functional limitation or pain seventeen years after surgery.

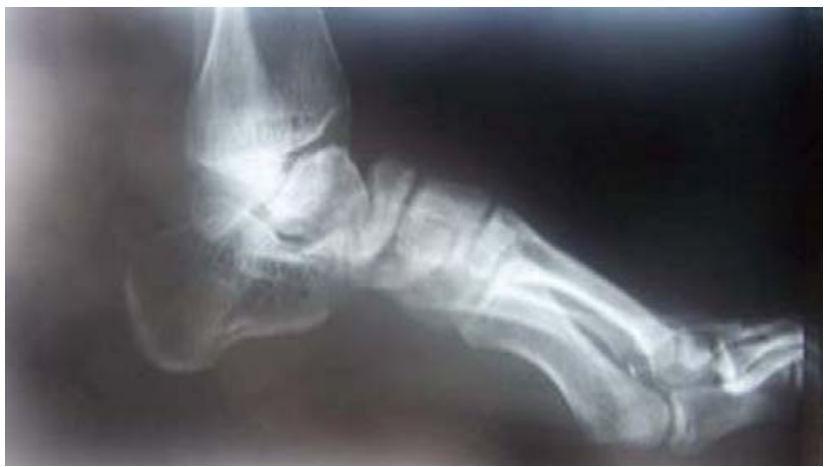

Figure 4 Lateral radiograph shows unusual contour to the talus and navicular bones. However, the overall contour of the joint is maintained.

\section{References}

1. Turco VJ. Surgical correction of the resistant club foot. One stage posteromedial release with internal fixation: A preliminary report. JBJS [Am] 53: 477- 497, 1971.

2. Turco VJ. Resistant congenital clubfoot-one stage posteriomedial release with internal fixation. A follow-up report of a fifteen year experience. JBJS 61A (6):805-14, 1979.

3. Rumyantsev NJ, Ezrohi VE. Complete subtalar release in resistant club foot. A critical analysis of results in 146 cases . J Pediatric Orthop 17 (4): 490-495. 1997.

4. Brougham DI, Nicol RO. Use of the Cincinnati incision in congenital talipes equinovarus. J of Pediatric Orthop 8 (6): 696-698, 1988.

5. Naoiontck M. Clinical and radiographic appearance of congential talipes equino varus after successful nonoperative treatment. J Pediatric Orthop 16 (1): 67-72. 1996.

6. Cummings RJ. Bashore CJ, Bookout CB et al: Avascular necrosis of the talus after McKay clubfoot release for idiopathic congenital clubfoot. J Pediatric Orthop 21 (2): 221 - 224, 2001.

7. Laaveg SJ, Ponseti IV.Long term results of treatment of congenital club foot. JBJS. 62A (1): 23-31, 1980.

8. Magone JB ,Torch MA, Clark RN et al. Comparative review of surgical treatment of the idiopathic clubfoot by three different procedures at the Columbus Children's hospital. J Pediatric Orthop 9 (1): 49-58. 1989.

9. Tachdjian MO. In Pediatric Orthopaedics. Second Edition . p 2539-2540. WB Saunders Company, Philadelphia, 1990. 